Appendix B. Items used in the generation post-test (ERG-ERG with -pa used for illustration)

Transitive sentences

The bankers activated the account The patients thanked the doctor The nail burst the tyres The vet cured the dogs The mechanics repaired the engine The handymen mended the door The psychologist erased the memories The farmer gathered the crops

\section{Intransitive sentences}

The girl laughed in the playgrounds

The building collapsed during the earthquakes

The students ate in the lecture

The teams changed in the corridor

The crop grew in the fields

The pensioner slept in the cinemas

The loaves baked in the oven

The boys played in the street ku-bankers pa-account activated-o

ku-patients pa-doctor thanked-o

ku-nail pa-tyres burst-i

ku-vet pa-dogs cured-i

pa-engine ku-mechanics repaired-o pa-door ku-handymen mended-o pa-memories ku-psychologist erased-i pa-crops ku-farmer gathered-i

pa-girl ne-playgrounds laughed-o pa-building ne-earthquakes collapsed-o pa-students ne-lecture ate-i pa-teams ne-corridor changed-i ne-fields pa-crop grew-o ne-cinemas pa-pensioner slept-o ne-oven pa-loaves baked-i ne-street pa-boys played-i 